The Japanese Journal of Experimental

Social Psychology, 1987, Vol. 27, No.1, 95-102

〔展

望]

\title{
社会的相互作用場面における 身体的スティグマについて
}

\author{
慶応義塾大学 \\ 三 井宏隆
}

社会的相互作用場面においては, 他者をどのように認 知するかによって, その後の対応の仕方む異なってくる。 なかであ年齢, 性別, 容姿, 人種といった属性は一目瞭 然であることから, 相互作用の展開に大きな影響を及ぼ してきた。

とてろで, こうした対人行動に関する研究の多くは当 事者の一方を観察者とし, 他方を被観察者としたうえで, 後者の属性を変化させる方法をとってきた。むし属性間 に差異が見出されたならば，その差異をあたらした属性 が対人行動の規定因であるという考え方である。無論, その際には@両者の間に前もって相互作用がないてと, 回両者の間に立場の逆転などが生じないてと, といった 保証が必要であった。屯し, そてに現実社会の政治的, 経済的, また社会的な関係が持込まれた場合には, 観察 者の反応は実験者の予想しえないあのとなりうるからで ある。

たとえば近年の調査報告は, アメリカ社会では反黒人 感情 (antiblack racism) が一貫して隇少しているて とを示しているけれども, 実生活では逆に反感が強まっ ているとの指摘がなされている (Crosby, Bromley \& Saxe, 1980)。乙のことは従来の白人優位の社会的枠組 が変化し, 黒人の社会, 経済的地位の向上が白人の立場 を劦かすまでになってきたてとに対する白人の側のアン ビバレントな反応を示すあのと解釈されている。また, 社会的弱者に対する政治的配慮は彼等をして弱者である ことに甘んずることなく, 新たな社会的役割や権利を要 求する運動を組織化するまでになっている。その結果と して, 一般の人びとの社会的弱者と称される人びとに対 する態度屯また, 微妙に変化してきたように思われる。

他方では自動車事故や不慮の事故のために, それまで の生活が一変してしまうといった事態む珍しくない。そ うした状況に直面した人びとは身体の不自由さだけでな
く，それに付随する対人関係にあ悩まされることになる。 自分の思い通りにならないという点では, 対人関係にま つわるトラブルの方がより深刻である（三井，1985）。

たとえば Bullman \& Wortman (1977) は自動車事 故や鉄砲の取扱いミスなどによる脊䯑道損傷のため両手, 両足が麻痺した患者（29名）との面接を通じて, (1)他者 を非難する度合が強かったり, 事故は避りることができ たと思っている間は, リハビリテーションに取組む姿勢 が甘く, 真剣さが感じられないとと, (2)逆に自分自身を 非難する度合が強ければ, リハビリテーションにも真剣 であること，を明らかにしている。

本稿ではこうした問題の重要性を強調する立場から, 健常者と障害者の間に生じる相互作用を “Physical stigma” にまつわる対人行動の研究, という観点から 取りあげていくととにする。

\section{1. スティグマとは何か}

日常生活場面に扔いては, 氏, 素姓が判らない場合で あ, その人物がどのような集団に属しているかというこ とが相互作用に際しての重要な手掛りとなる。たとえ平 等を建前とする社会であってあ, そてには政治, 経済, 教育といった領域において優越的な地位を占める集団と 従属的な地位によどまらざるをえない集団とが存在する からである。両者の関係が固定したものであれば, 人び とは迷うことなく自らの所属する集団の価值観に照らし て, 他の集団の成員と接触するてとになる。そうした価 值観は多様な形で表現されるけれども, それがネガティ ブな評価や感情と結びついた場合が偏見や差別である。

この偏見や差別の問題については，「偏見や差別は何 歳頃から現われるのか」,「それはどの程度根強いあので あるか」といったテーマのもとに, 数多くの研究がなさ れてきた。

（注）本稿では文脈に応じて, 障害者, スティグマを負う人，スティグマを付与された人, physical stigmaをむ つ人といった用語の使い分けがなされているが，その意味するとてろはほとんど同じである。 
そうしたなかで，近年スティグマ (stigma) という言 葉が研究者の間で使用されるようになってきた。スティ グマという概念の導入は社会的相互作用の問題を研究す るうえで,一体どのような意味をむつのであろうか。

乙の点について, 先駆的な研究を行なった Goffman, E. (1963) はスティグマの語源を古代ギリシャに扔いて 奴隷や犯罪者の身体に刻みつけられたり，焼きつけられ た烙印に求めると同時に, 今日ではそれが拡大解釈され て, 不面目自体をいい表わす言葉として用いられている ことを指摘した。すなわち, 特定の個人に関する問題か ら，その個人をとりまく人びとの態度の問題へと関心が 移行することになったのである。

Katz, I. $(1979,1981)$ は近年に扔いて集団間の関係 を扱った研究が多くなってきたてとを指摘したうえで, (1)白人の黒人に対する態度, 一般の人びとが犯罪者, 精 神病患者, 身体障害者に示す態度には共通したものがあ り，それを明確にするためには何らかの統一概念が必要 であるてと，スティグマという概念はその有力な候補 になりうるてと，を主張した。彼によ扎ば, スティグマ 之は, 「社会的に優越的な地位を占める集団の成員が, 自分たちとは異なる集団の成員に対して示す偏見にみち た反応を説明するために提出された概念であり, 社会的 に受入れがたい属性を意味する言葉」であった。

さらに, Jones, Farina, Hastorf, Markus, Miller \& Scott (1984) はステレオタイプ (stereotype) とステ ィグマの異同について論じている。ステレオタイプと は自分自身で説明がつかなかったり，正当化しえないよ うな感情に由来するあのであり，そうした不快感や敵意 を合理化するために他者の属性のなかからネガティブな あのをみつけ出す心理過程である。@スティグマとは否 定的感情だけでなく, 肯定的感情も同時にもつアンビバ レントな状態を特徴とする心理過程である。

このように, スティグマという概念は偏見, 差別とい った問題のほかに, 正常と異常, 規範と逸脱, 社会的弱 者といった今日的な問題を取り扱ううえでの視点を与え るものであるが, そうしたスティグマの付与 (stigmatization) をもたらす心理的背景を前述の Katz は次の 3 つの理論モデルにまとめている。(1)帰属モデル (attribution)……ネガティブな意味合いをもつ属性や特性 を有するととが直接的に当該人物のネガティブな評価に 結びつく。(2)ラベリングモデル (labelling) ……社会的 亿優越的な地位を占める集団の成員が或る種の行動や属 性を社会的基準加逸脱している，と判断するてとによ って，そうした属性を有する当該人物もまた，ネガティ ブな評価をうける。(3)贖罪の山羊モデル (scapegoat)
……他の原因から生じた怨恨や怒りが特定の集団の成員 に向けられることから生じる。

それではスティグマを付与された人は一般の人びと (non-stigmatized person) との相互作用に拈いて, ど のようなハンディキャップを負わざるをえないのであろ うか。

Goffman はスティグマという概念はそのなかに， (1)身体的欠陥 (bodily abominations); (1)個人の性格 に由来する污点 (character blemishes), @人種, 民族, 宗教といった集団間の葛藤, 対立にかかわる屯の (tribal stigma), といった 3 種類のあのを含んでいると述べ ているが, Jones et al., はそれを社会的相互作用の観 点から 6 つの行動次元に分けている。

(1) 人目にふれる度合 (concealability) ……それは 他者の目からどの程度隠しおおすことができるのか。

(2) 心理的負担の度合 (course)……それは当人にと って一時的な性質のものか, それとも一生背負っていか ざるをえないような性質のあのか。

(3) 相互作用の障害となる度合 (disruptiveness) … …そのために他者とのコミュニケーションが妨げられた り, 相互作用がうまくいかなかったりすることがあるの か。

(4) 美醜の度合 (aesthetic qualities) ……とのため に他者が嫌悪感を抱いたりすることがあるのか。

(5) 当人の責任の度合 (origin) ……何が原因でその ようなととになったのか, 責任は彼自身にあるのか。

(6) 恐怖感を与える度合 (peril)……そのために他者 が危険を感じたり, 関わりあうことを避けるといったて とがあるのか。

無論，乙れらはそれぞれが単独で影響を及ぼすのでは なく, 相互に関連しあっているのが実情である。またて のほかにむ, (1スティグマの種類, @スティグマを付与 された人物の個人的要因 (背の高さ, 顔つきなど), @相 互作用の性質, なども対人行動の在り方に関係してくる 筈である。

たとえば, Pollack, Huntley, Allen \& Schwartz (1976) は一般の人びとが同性愛者之精神病患者に対す るときの行動には差異がみられることを指摘しており,

McGarry \& West (1975) は精神遅滞者の言語能力, 容 姿, 施設内の移動能力といった要因か職員との相互作用 の在り方に大きな相違をむたらしているてとを明らかに した。

このようにスティグマと称されるあののなかには多様 なタイプが含まれており，一般の人びとの反応もタイプ 如何によっては異なったものとなるが, 本稿では論点を 
明確にするために physical stigma に対する健常者の 反応に焦点をあてるてとにする。

\section{Physical stigma をめぐる相互作用}

一般の人びとが physical stigma をむつ人に示す反 応はアンビバレントなむのであると言われている。それ は@彼との接触を回避しょうとする心情と, 回彼には親 切でなり机ばならないとする社会規範，との衝突があた らすジレンマである。

ての点について, Kleck, Ono \& Hastorf (1966) は 健常者が車椅子の人から面接をうけるといった状況を設 定することによって，健常者の側の反応を観察した。そ の結果, 面接者が健常者である場合と比較して, (1)面接 場面にとどまる時間か短くなるとと, (2)回答内容が紋切 り型となるとと, (3)本心を明らかにしないてと, が明ら かにされた。

さらに Kleck, R. E. (1968) は両者の相互作用をめぐ る非言語水準の反応に着目した。被験者は中学, 高校生 の男子15名であり，彼等は 2 回ずつ個別実験に参加した。 彼等が実験室にやってくると, 実験者は「本日の実験目 的は相互作用場面に打ける生理的反応の測定である」と 説明した後で彼の手に電極を貼付した。一方, 相手役と なるサクラは, (a車椅子条件 (disabled) 或いは®普通 条件 (normal) のもとで現われた。乙の時点で改めて 両者の生理的反応測定装置を点検した所, 被験者に割り 当てられた装置がうまく作動しないことが判明したとの 理由で,「今回の測定はサクラだけにとどめ, 被験者に ついては取りやめる」と伝えた。乙れは被験者の注意を 本来の実験目的に集中させるための口実であった。次い で相互に個人情報を交換するとの名目で，実験者が読み あげる質問項目に対して被験者, サクラの順序で回答す るように求められた。項目内容は，(1)手短加に自分自身 を語るとと, @学校生活におけるスポーツ活動の意義, 学業の重要性, というあのであった。乙の間の被験者 の様子はすべて録画されていた。最後に相互の印象評定 が行われた。また実験の第 2 部として 3 日後に同じこと が繰返されたが，そのときはnormal $\rightarrow$ disabled, disabled $\rightarrow$ normal といった形で前回と異なる条件操作が なされた。実験結果からは, disabled 条件での被験者 の反応は normal 条件と比較して, (1)身体の動きがよ り少なかったてと，(2)相手に対してより好意的な印象を 形成していたてと, (3)自分の意見を相手に合わせようと する傾向が強くみられたてと, が明らかにされた。但し, アイ・コンタクト (eye contact) は減少するであろうと の予想は支持されなかった。

てれに対して, Comer \& Piliavin (1972) 障害者自 身が健常者との相互作用をどのように受けとめているか という問題をとりあげた。被験者はペンシルベニア大学 附属病院及びリハビリテーション・センターに入院中の 30名の男性患者であった。その内訳は, 手足を切断した 患者12名, 両足麻瘏の患者 10 名, 半身不随の患者 8 名で あった。実験の目的は, 「初対面の人同士に打ける出会 いの研究である」と説明された。実験者は車椅子を押し て 1 人ずつ実験室を案内し, 部屋の様子を説明した後で, 「あなたの知らない男の人が質問項目を読みあげ，あな たが回答することになる」と伝えた。後から入室したサ クラは, @車椅子条件 (handicapped) と回椅子を手に して入ってくる条件 (normal), とに割り当てられた。 いずれの場合にもサクラが実験室内に所定の位置を占め た後, 被験者自身が車椅子を移動させてサクラとの面接 距離を設定するてとになっていた。それからサクラは， 「第 1 問は自分自身について語ることです。で自由にお 話し下さい。終わりました所で第 2 問に移ります」とい う形で10個の質問を繰返した。実験は最後に被験者が別 室で一連の質問に回答することで終了した。実験結果は 次の通りである (Table 1)。Normal 条件の被験者は Handicapped 条件の場合と比較して, (1)面接をより早 い時間内に終了させていたてと，(2)面接場面ではできる だけ身体を動かさないようにしていたてと，(3)笑いの表 出屯少なかったてと, (4)面接者とのアイ・コンタクトあ 少なかったてと，5面接そのものに好意的な印象をむっ ていなかったてと，が明らかにされた。

Table 1

面接場面における両条件群の反応の比較

\begin{tabular}{|c|c|c|c|c|c|c|}
\hline & $\begin{array}{c}\text { 面 接 時 間 } \\
\text { (単位は分) }\end{array}$ & $\begin{array}{l}\text { 面接時間内での } \\
\text { 身体の動き }\end{array}$ & $\begin{array}{l}\text { 両者の対人距離 } \\
\text { (単位はインチ) }\end{array}$ & $\begin{array}{l}\text { 面接時間内での } \\
\text { 笑いの 時 間 }\end{array}$ & $\begin{array}{l}\text { 面接時間内での } \\
\text { 笑いの 回 数 }\end{array}$ & $\begin{array}{l}\text { アイ・コンタクトの } \\
\text { 占めるパーセント }\end{array}$ \\
\hline $\begin{array}{l}\text { Normal } \\
\text { 条 件 }\end{array}$ & 6.55 & 0.093 & 67.5 & 0.091 & 0.028 & 13.2 \\
\hline $\begin{array}{l}\text { Handicapped } \\
\text { 条 件 }\end{array}$ & 9.56 & 0.135 & 79.2 & 0.098 & 0.041 & 23.0 \\
\hline
\end{tabular}

（注）各条件とも15名の平均值。 
このととは障害者自身もまた, 健常者との相互作用を 苦痛なむのと考えているととを示すものであった。

また, 両者の相互作用を援助行動の場面で取りあげた のが Doob \& Ecker (1970) である。彼等は家庭の主婦 を被験者として実施した戸別訪問に扔いて，(1)面接者が 眼帯をしているか否か, 回回答は面接法か留置法か, 亡 いった条件操作をしたうえで, 回答の承諾率を比較した。 その結果によると, (1)留置法を採用した場合には眼帯を しているてとが承諾率を有意に高めたのに対して, (2)面 接法では眼帯の効果は見出されなかった。彼等はこの結 果について, スティグマをむつ人との接触が今回限りと いう状況では承諾率が高まると説明した。しかしながら， Soble \& Strickland (1974), Levitt \& Kornhaber (1977) は眼帯をしていることが果してスティグマ条件 とみなしうるかという疑問を表明した。そこで Levitt \& Kornhaber は, 足が不自由な様子のサクラを用いて, 通行人に小銭を要求する状況を設定する一方, 足のけが が一時的なむのかどうかを条件操作した。その結果は, 足の不自由なとと (physical handicap) が援助行動を 引出しており, 完治しえないてと (physical stigma) は援助行動に影響を及ぼしていなかった。

この点は, Samerott \& Harris (1976) の実験でも同 様であり, physical handicap は援助行動を引出すけ れどあ, physical stigma は逆に減少させるて.とを示 していた。

とてろで, 社交辞令とかお世辞といった言葉か示すよ うに，本当のことを相手に伝えることが必ずしも望まし くない社会状況がある。たとえば，障害者のパフォーマ ンスについて評価を求められた場合, 健常者はどのよう な評価を下すであろうか。

Hastorf, Northcraft \& Picciotto (1979) の実験結 果では, 障害者の場合には健常者と比較して, たとえ不 満足な作業成績であっても好意的に評価されるというこ とであったのに対して, Russell, Lenel, Spicer, Miller, Albrecht \& Rose (1985) は逆の結果を報告してい る。すなわち, 彼等は女子学生に算数の問題に取組んで いる男の子のビデオテープを観察するように求める一方 で, 実験条件として, (1) の男の子が身体障害者か否か, @算数の成績の良否, を取りあげた。その結果は障害者 であることが逆にネガティブな評価に結びつくというあ のであった。

両者の結果の相違は障害者之の対面の可能性の有無之 いった手続上の相違にあよるあのと思われるが, Carver, Glass \& Katz (1978) はスティグマをもつ人に示され る好意的反応は (positive prejudice), 健常者が社会的

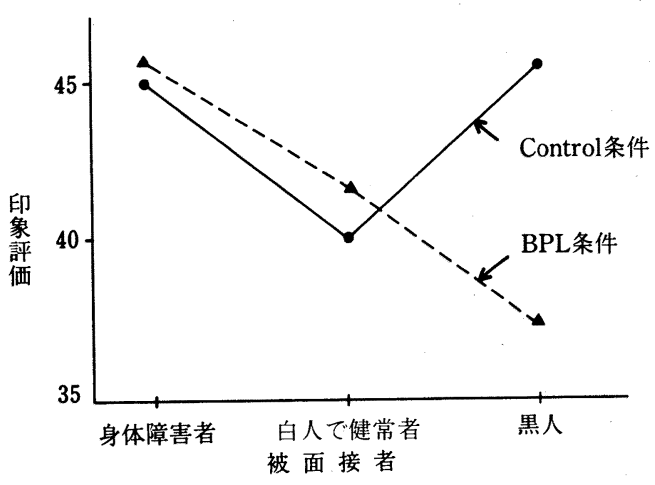

Fig. 1 異なる評定方法のもとでの印象評価

に望ましいとされる反応を意識的に採用した結果ではな いかと考えた。そてで Bogus Pipeline (BPL) という 嘘発見器に似た装置を使用するてとにより，「嘘をつい てもすぐにわかってしまう」と思い込ませたうえで, 被 験者の反応を求めることにした。被験者の女子学生は印 象形成に関する実験ということで, ランダムに(1) BPL 条件之回通常のチェックリストを使用する Control 条 件, に割りふられた。実験課題は或る人物に関する面接 記録を読んで印象評価を行なうことであった。実験条件 は当該人物が@黒人, 身体障害者, 白人で健常者, という指定であった。従属変数は11項目からなる印象評 価であった。実験結果は BPL 条件において, 被面接者 が黒人の場合に有意にネガティブな評価となっていた。 また評定方法にかかわりなく, 身体障害者に対する評価 は好意的であった。乙のととは身体障害者に対するネガ ティブな感情の表出は, 黒人に対する場合よりあ社会的 に強く抑制されているためである, と解积された（Fig. 1)。

\section{3. スティグマの付与がもたらす影響}

Goffman, E. (1963) はスティグマを付与された人び とが一般の人びととの関係に扔いて学習すべき事柄とし て, (1まず健常者の視角を習得するてと, @司の視角か ら見て自分が失格していることを理解するてと，そう したカテゴリーに含まれる人びとの処遇のされ方に自分 を慣らしていくこと，をあげている。

すなわち，彼等の社会関係は一般の人びとが自分たち を社会的に不適格な存在と見做しているという事実を受 け入れることから始まるのである。

また, Jones, et al., (1984) はスティグマを付与さ れた人びとは社会的弱者の立場に置かれており, そうし た状沉に適応するためには強者の立場にある人びとが彼 
Table 2

スティグマを付与された人びとの対人意識

\begin{tabular}{lrcc}
\hline \multirow{2}{*}{ 評定尺度 } & \multicolumn{3}{c}{ スティグマ条件 } \\
\cline { 2 - 4 } & $\begin{array}{c}\text { アレルギー体 } \\
\text { 質 }\end{array}$ & てんかん & 顔の傷痕 \\
\hline Eye contact & 12.00 & 10.37 & 11.75 \\
Tenseness & 2.37 & 7.12 & 8.00 \\
Talking & 9.37 & 9.37 & 10.37 \\
Distance & 7.37 & 7.87 & 8.62 \\
Attraction & 8.62 & 7.50 & 6.37 \\
Liking & 10.25 & 8.87 & 9.75 \\
Patronization & 1.87 & 3.25 & 4.12 \\
\hline
\end{tabular}

（注）各評定尺度は14段階評定。数值が大きいほど, その特 性を有するとみなされる。

等に課する所の役割行動——すなわち “child among adults” role——をとるととを余儀なくされていると 主張した。

ところで, Kleck \& Strenta (1980) はスティグマを あつことがその人の行動にどのような影響を及ぼしてい るかを検討している。彼等は女子学生を被験者にして, (1)アレルギー体質の人，てんかん患者，顔傷痕の ある人，といった条件にランダムに割り当てた後，「同 年齢の女子学生(サクラ) と或るテーマについて話し合い をすることになる」と伝えた。各被験者は自分がどのよ うな状態にあるかを相手は承知しているあのと思い込ん でいたけれども, 実際の所, サクラは被験者がどのステ ィグマ条件であるかを知らなかった。両者は「友達をつ くる方法」というテーマで約 6 分間話し合ったが, 被験 者にはその後, @少ララついての印象評定と@話しあ っている場面のビデオテープを見て，気づいたてとをチ エックするとと, が求められた。実験結果からは, 社会 的にネガティブな評価が与えられやすい属性を付与され た条件の被験者は（てんかん及び顔の傷痕），社会的な 評価が曖昧な属性の持主と比較して（アレルギー体質）, 相手の何気ない反応にも過敏になっているととが明らか にされた。すなわち，(1)顔に傷痕のある人は相手の視線 が気にかかると同時に，それに特別な意味づけを与えて しまうこと, (2)てんかんの人は相手の反応に緊張感や不 安気な様子を読みとってしまうことなどである (Table 2)。

てのようにスティグマを付与された人びとが周囲の人 びとの立居振舞を強く意識しているということになると， 一般の人びとはそうした煩わしさを恐れて関わりあいを 避けるようになる。乙れは一種の悪循環であり, 両者の
相互理解はいよいよ難しいものとなる。

こうした状況を打開する方策として提案されたのが, スティグマを付与された人が進んで自らのスティグマに ついて語るというものであった。その狙いは一般の人び とが彼等について抱いている不安感を事前に解消してし まうことであった。

Belgrave \& Mills (1981), Mills, Belgrave \& Boyer (1984) は Farina, Sherman \& Allen (1968), Hastorf, Wildfogel \& Cassman (1979) らの先行研 究を批判的に検討したうえで次のような実験を行なった。 Belgrave \& Mills は女子学生を被験者にして,「他者 との相互作用が作業課題に及ぼす影響」という名目で, 最初に他者との相互作用を好む度合を10段階で評定する ように求めた (Pretest)。評定後に「ての評定用紙は今 回の実験では使用しないてとになっていたので，新しい 用紙を取りにいってくる」との口実をあうけて実験者は 退出した。その間, 被験者と遅れてやってきたサクラの 男性は質問紙に回答しているようにと言われた。サクラ については, (1) disabled 条件と(a) nondisabled 条件 が設定されていた。 disabled 条件では車椅子の状態で あったが, 被験者に対して次のような条件操作を行なっ た。(1) Request-mention 条件……クラが質問紙に回 答しているときに鉛筆の芯が折れてしまい, 被験者に向 かってそれとなく「鉛筆の芯が折れてしまったので削っ てくれませんか。車椅子では高い所に置かれた鉛筆削ま で手がとどきませんので」と抔願いした。(2) Miscuemention 条件……クラか質問紙に回答しているとき に鈆筆の芯が折れてしまい, 鉛筆削がある所まで車椅子 を移動させていき削ろうとしたが，鉛筆を取り落として しまった。そてで被験者に向かってそれとなく「車椅子 では不都合なととが多い。鉛筆を削るのあ大変だ」とつ ぶやいた。(3) Mention 条件……クラは被験者に向か ってそれとなく，「ての実験が身体を動かすあのでなけ ればよいのだが。車椅子では不都合なことが多い」とつ ぶやいた。(4) No mention 条件と(5) Nondisabled 条 件では, サクラは質問紙に集中しており, 被験者に向か っての発言はなかった。実験者はてれらの様子を観察し ており，(1)〜3の条件では被験者が何らかの反応を示し た所で, (4)〜5)の条件では被験者が回答を終えた所で入 室した。そして被験者を別室に案内し, 新しい評定用紙 を手渡して「他者との相互作用を好む度合」を20段階で 評定するように求めた (Posttest)。従属変数は Posttest と Pretestにおける評定值の差異であった（但し， Pretest の評定値は Posttest の尺度值にあわせて修正)。 実験結果は予想通り, サクラがあっともらしく自分の 
Table 3

相互作用に対する好意度の変化

\begin{tabular}{|c|c|c|c|}
\hline \multirow{2}{*}{ 条 } & 尺 & 度 & 值 \\
\hline & Pretest & & Change \\
\hline Nondisabled & 8.0 & & -0.10 \\
\hline No mention & 8.0 & & -0.45 \\
\hline Mention & 8.0 & & -0.15 \\
\hline Request-mention & 7.6 & & +1.15 \\
\hline Miscue-mention & 7.0 & & +0.65 \\
\hline
\end{tabular}

（注）各条件とも被験者は20名。数值は平均值。

身体状態に言及した場合において (Request-mention, Miscue-mention 条件), より好意的態度が引出された。 しかしながら，単に身体の状態に言及するだけでは十分 な効果はえられなかった (Table 3)。

\section{Physical stigma に対する行動の説明}

健常者の physical stigma をむつ人に対する行動を 説明するために，てれまでにいくつかの仮説が提出され てきた。

Langer, Fiske, Taylor \& Chanowitz (1976) は健 常者の行動を(1) physical stigma に対する好奇心と, (口それを不躾なとととして禁ずる社会規範との㵧藤から 説明する新奇刺激仮説 (novel-stimulus nypothesis) を提唱した。彼等によれば, 乙の葛藤から最終的によ゙の ような行動が生じてくるかは, (1)スティグマを熟知して いる度合, (2)彼等を凝視することを禁じた規範に違反し た場合の制裁の強さ，(3)そうした状況からの逃避の容易 さ，によって決定されるてとになる。乙の仮説を実験に よって検証するために，第 1 実験では凝視してあひんし ゆくをかうことの少ない写真が使用された。一組 3 枚の 写真（足が不自由な女性, 妊娠した女性, 普通の容姿の 女性の写真）を大学内のレストランに展示するて.とによ って，そてにやってきた人びとが写真を凝視する時間を 測定した (Table 4)。第 2 実験では背中の曲った男性の 写真を使用する一方, その場他他者がいる状況を設定し て,「他者を凝視するてとを禁じた社会規範」を意識化 させるととにした。第 3 実験では予め相手がどのような 人物かを知っているてとが，好奇心を減ずるてとになる のかを検討した。実験結果はいずれ屯新奇刺激仮説を支 持するあのであった。但し, physical stigmaをあつ人 を中傷するといった現象は見出されなかったてとから， てれらの人びとを犯罪者や精神病患者之区別して考える べきであることが示唆された。
Table 4

各女性の写真の凝視時間 (単位は秒)

\begin{tabular}{|c|c|c|c|}
\hline \multirow{3}{*}{ 被 験 者 } & 刺 & 激 の 新 奇 & 性 \\
\hline & 足が不自由な & \multirow{2}{*}{ 妊娠した女性 } & 普通の容姿の \\
\hline & 女 性 & & 女 性 \\
\hline 性 & 3.85 & 2.63 & 2.11 \\
\hline 性 & 2.14 & 1.57 & 2.29 \\
\hline
\end{tabular}

（注）被験者は男女とも各15名。数值は平均值。

同じくSnyder, Kleck, Strenta \& Mentzer (1979) は健常者が時として physical stigma をもつ人に示す 好意的態度はできれば彼等との接触を避けたいという本 心の裏返しであり, あし適当な口実があれば接触は回避 されるであろうと考えた。そこで健常者が 2 人のサクラ

（身体障害者と健常者）と同席する事態を設定し，(1)同 じ映画を鑑賞せざるをえない条件と，可異なる映画の鑑 賞が可能である条件とに扔いて, どちらのサクラと一緒 にいたいかを尋ねた。その結果, (1)条件では身障者と の同席を好む割合が高かったのに対して, 问の条件では 健常者が好まれていた。

一方, Katz, I. (1981) は健常者が physical stigma をあつ人に抱く感情は，〕友好，同情，受容といった側 面之, @敵対, 中傷, 拒否といった側面とが入りまじっ たアンビバレントなあのであり, 両者の拮抗する度合が 強ければそれだけ極端な反応となって現われるという アンビバレント行動増幅仮説 (ambivalence-induced behavioral amplification) を提唱した。

たとえば, Carver, Gibbons, Stephan, Glass \& Katz (1979) は女子学生を被験者にして所定の面接記録 を読んで当該人物の印象を評定するように求めた。提示 された人物は，(1)車椅子を使用せざるをえない人，(口) キシコ人，健常者であり，それぞれについて好意的内 容と非好意的内容の面接記録が用意された。乙てで問題 となるのが事前操作であり, 半数の被験者に対しては実 験が始まる前に男子学生がやってきて, 身障者の入学定 員枠の拡大をめぐって相対立する意見を掲載したパンフ レットを読むように求めた。乙れは身障者に対するアン ビバレントな感情を増幅する手段とみなされた。実験結 果は予想通り, 事前操作を受けた場合, 好意的な内容の 面接記録を読んだ条件群では身障者に対してよりポジテ ィブな方向に変化し, 非好意的な内容を読まされた条件 群ではよりネガティブな方向に変化した (Table 5)。

また Linville \& Jones (1980) は異なる文脈のむとで の研究ではあるが, 人びとの評価は内集団の成員に対す る場合と外集団の成員に対する場合とでは相違がみられ 
三井：社会的相互作用場面における身体的スティグマについて

Table 5

面接記録の当事者に対する好意度

\begin{tabular}{|c|c|c|c|c|c|c|c|c|}
\hline & \multicolumn{4}{|c|}{ 好意的な内容の面接記録 } & \multicolumn{4}{|c|}{ 非好意的な内容の面接記録 } \\
\hline & \multicolumn{2}{|c|}{ 事前操作あり } & \multicolumn{2}{|c|}{ 事前操作なし } & \multicolumn{2}{|c|}{ 事前操作あり } & \multicolumn{2}{|c|}{ 事前操作なし } \\
\hline & 平 均 & 人数 & 平 均 & 人数 & 平 均 & 人数 & 平 均 & 人数 \\
\hline 身 障 者 & 104.47 & 19 & 99.20 & 21 & 64.90 & 20 & 71.39 & 23 \\
\hline メキシコ人 & 101.33 & 18 & 88.10 & 21 & 59.95 & 20 & 64.29 & 24 \\
\hline 健 常 者 & 101.61 & 18 & 93.95 & 20 & 57.00 & 21 & 58.96 & 23 \\
\hline
\end{tabular}

（注）数值が大きい程より好意的な評価を示す。

るととを指摘した。すなわち，(1)人びとは外集団に関し てよりあ, 自分が所属する内集団について複雑な認知図 式を形成しているてと, (2)その結果として, 外集団のメ ンバーに対する評価はより極端なむのになりやすいてと， (3)たとえば同じょうな好意的情報が与えられたとしてあ、 外集団の成員に対する評価は内集団に対する場合と比較 してよりポジティブなものとなるが, 否定的情報ではよ りネガティブな方向に傾きやすいてと，を明らかにした。 こうしてみると, physical stigmaをもつ人に対する ネガティブな評価は本来認知図式の発達が不十分な所に, 否定的な情報のみが与えられたためと考えられる。

ての点について, Scheir, Carver, Shultz, Glass \& Katz (1978) は physical stigma をむつ人に関する個 人的な情報の提示が好意的評価をむたらすと述べており， Lerner \& Miller (1978) は彼等との同一視が差別的言 動を抑制させると主張する。しかしながら destigmatization の問題については, 個人的な対応だけでは不十 分であり, 法律などの制度面での努力, マスコミなどに よる啓蒙活動, さらには社会的弱者と称される人びとの 意識改革もまた必要と思われる。

\section{引用文 献}

Belgrave, F.Z. \& Mills, J. 1981 Effect upon desire for social interaction with a physically disabled person of mentioning the disability in different contexts. Journal of Applied Social Psychology, 11, 44-57.

Bullman, R. J. \& Wortman, C. B. 1977 Attributions of blame and coping in the "Real world": Severe accident victims react to their lot. Journal of Personality and Social Psychology, 35, 351-363.

Carver, C. S., Gibbons, F. X., Stephan, W. G., Glass, D. C. \& Katz, I. 1979 Ambivalence and evaluative response amplification. Bulletin of the Psychonomic Society, 13, 50-52.
Carver, C.S., Glass, D. C. \& Katz, I. 1978 Favorable evaluations of blacks and the handicapped. Journal of Applied Social Psychology, 8, 97-106.

Commer, R. J. \& Piliavin, J. A. 1972 The effects of physical deviance upon face-to-face interaction: The other side. Journal of Personality and Social Psychology, 23, 33-39.

Crosby, F., Bromley, S. \& Saxe, L. 1980 Recent unobtrusive studies of black and white discrimination and prejudice: A literature review. Psychological Bulletin, 87, 546-563.

Doob, A.N. \& Ecker, B.P. 1970 Stigma and compliance. Journal of Personality and Social Psychology, 14, 302-304.

Farina, A., Sherman, M. \& Allen, J. G. 1968 Role of physical abnormalities in interpersonal perception and behavior. Journal of Abnormal Psychology, 73, 590-593.

Goffman, E, 1963 Stigma. Prentice-Hall. (石黒毅 訳 スティグマの社会学 せりか書房 1970)

Hastorf, A.H., Northcraft, G.B. \& Picciotto, S.R. 1979 Helping the handicapped: How realistic is the performance feedback received by the physically handicapped? Personality and Social Psychology Bulletin, 5, 373-376.

Hastorf, A.H., Wildfogel, J. \& Cassman, T. 1979 Acknowledgment of handicap as a tactic in social interaction. Journal of Personality and Social Psychology, 37, 1790-1797.

Jones, E. E., Farina, A., Hastorf, A. H., Markus, H., Miller, D. T. \& Scott, R. A. 1984 Social stigma: The psychology of marked relationships. Freeman.

Katz, I. 1979 Some thoughts about the stigma notion. Personality and Social Psychology Bulletin, 5, 447-459.

Katz, I. 1981 Stigma: A social psychological analysis. Lawrence Erlbaum Associates.

Kleck, R.E. 1968 Physical stigma and nonverbal cues emitted in face-to-face interaction. 
Human Relations, 21, 19-28.

Kleck, R. E., Ono, H. \& Hastorf, A. H. 1966 The effects of physical deviance upon face-toface interaction. Human Relations, 19, 425 -436 .

Kleck, R. E. \& Strenta, A. 1980 Perceptions of the impact of negatively valued physical characteristics on social interaction. Journal of Personality and Social Psychology, 39, 861-873.

Langer, E.J., Fiske, S., Taylor, S.E. \& Chanowitz, B. 1976 Stigma, staring and discomfort: A novelstimulus hypothesis. Journal of Experimental Social Psychology, 12, 451-463.

Lerner, M. J. \& Miller, D. T. 1978 Just world research and the attribution process: Looking back and ahead. Psychological Bulletin, 85, 1030-1051.

Levitt, L. \& Kornhaber, R. C. 1977 Stigma and compliance: A re-examination. Journal of Social Psychology, 103, 13-18.

Linville, P.W. \& Jones, E. E. 1980 Polarized appraisals of out-group members. Journal of Personality and Social Psychology, 38, 689703.

McGarry, M.S. \& West, S.G. 1975 Stigma among the stigmatized: Resident mobility, communication ability and physical appearance as predictors of staff-resident interaction. Journal of Abnormal Psychology, 84, 399405.

Mills, J., Belgrave, F. Z. \& Boyer, K. M. 1984 Reducing avoidance of social interaction with a physically disabled person by men- tioning the disability following a request for aid. Journal of Applied Social Psycho$\log y, 14,1-11$.

三井宏隆 1985 スティグマの社会心理学 三田哲学会 紀要, 81, 99-120.

Pollack, S., Huntley, D., Allen, J. G. \& Schwartz, S. 1976 The dimensions of stigma: The social situation of the mentally ill person and the male homosexual. Journal of Abnormal Psychology, 85, 105-112.

Russell, D., Lenel, J, C., Spicer, C., Miller, J., Albrecht, J. \& Rose, J. 1985 Evaluating the physically disabled: An attributional analysis. Personality and Social Psychology Bulletin, 11, 23-31.

Samerotte, G. C. \& Harris, M. B. 1976 Some factors influencing helping: The effects of a handicap, responsibility and requesting help. Journal of Social Psychology, 98, 3945.

Scheier, M. F., Carver, C. S., Schultz, R., Glass, D. C. \& Katz, I. 1978 Sympathy, self-consciousness and reactions to the stigmatized. Journal of Applied Social Psychology, 8, 270-282.

Snyder, M.L., Kleck, R.E., Strenta, A. \& Mentzer, S. J. 1979 Avoidance of the handicapped: An attributional ambiguity analysis. Journal of Personality and Social Psychology, 37, 2297-2306.

Soble, S. \& Strickland, L. H. 1974 Physical stig$\mathrm{ma}$, interaction, and compliance. Bulletin of the Psychonomic Society, 4, 130-132.

-1985年 4 月 25 日 受稿, 1987 年 3 月 10 日 受理一 